\title{
WORLD LAW
}

\section{THE GUBAN QUARANTINE: SOME IMPLICATIONS FOR SELF-DEFENSE}

\author{
Daniel G. Partan*
}

I

Self-Defense and the Charter: Conflicting Theories
$T_{\text {he naval quarantine of Cuba in October and November, 1962, }}$ has given sharp focus to one of today's most heated disputes between international legal scholars, namely the proper scope of the right of states to use force in self-defense. In recent years, scholars have devoted considerable attention to the role and function of law in controlling the use of force by states, ${ }^{1}$ and have developed several distinct approaches to the problem in terms of the law of the United Nations Charter. The crux of the dispute is the relationship between articles 2(4) and 51 of the U.N. Charter and the impact of these articles on the right to use force in self-defense. Article 2 (4) formulates the basic Charter prohibition on unilateral use of force in the following terms:

All Members shall refrain in their international relations from the threat or use of force against the territorial integrity or political independence of any state, or in any other manner inconsistent with the Purposes of the United Nations.

The first sentence of article 51, the only article which mentions selfdefense, provides that:

- A.B. 1955, Cornell University; LL.B. 1958, LL.M. 1961, Harvard University; Research Associate, World Rule of Law Center, Duke University.

1 Recent major works include the following: BowETT, SELF-DEFENSE IN INTERNATIONAL LAW (I958); BrowneIE, INTERNATTONAL LAW AND THE USE OF Force BX STATTS (1963); McDougal \& Associates, Studies in World Public Order (1960); McDougal \& Feligiano, Law and Minimum World Public Order: Legal Regulation of International COERcion (1961); StONE, LEgal Controls of InTERnatTonal Conflict (1959); Stone,

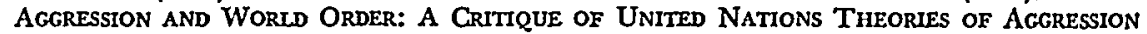
(1958); WRIGHT, The Role OF INTERNATIONAL LAW IN THE ELIMINATION OF WAR (1961). BRownLIE, supra at 475-519, contains an extensive Bibliography of Books and Articles on the Law Relating to the Use of Force by States. See also Green, Selected Bibliography on Some Aspects of the Principle of Self-Defense, in INT'L LAW Ass'N, REPORT OF THE 48TH CONF., NEW YoRK, 1958, at 622-28 (1959); and Ass'n of the Bar of the City of N.Y. Library, Selected Bibliography on the Cuban Crisis, in THE INTER-AMERICAN Securrty System and the Cuban Crisis (Hammarskjold Forum No. 3, Tondel ed. 1963). 
Nothing in the present Charter shall impair the inherent right of individual or collective self-defense if an armed attack occurs against a Member of the United Nations, until the Security Council has taken measures necessary to maintain international peace and security. ${ }^{2}$

One reading of these Charter provisions is that the article 2 (4) prohibition on the use of force by states is absolute except for the "inherent right" to use force in self-defense "if an armed attack occurs," which right exists in the post-Charter world only as thus defined in article 51.3

Another approach would treat article 51 as a special case included in the Charter to make crystal clear that collective self-defense arrangements, such as the Inter-American Act of Chapultepec, ${ }^{4}$ were not prohibited. Proponents of this view point out that there is no evidence in the San Francisco documents that, by including article 51, the Charter makers sought either to define or to limit the circumstances under which force may be used in self-defense, but that the San Francisco documents do make clear that article 2 (4) was not intended to prohibit the use of force in legitimate self-defense. ${ }^{5}$ Under this view, therefore, the circumstances under which selfdefense is "legitimate" are to be derived from general international law. ${ }^{6}$

2 The Charter of the United Nations, June 26, 1945, 59 Stat. 1031, T.S. No. 993, is hereinafter cited as U.N. CHARTER. U.N. CHARTER art. 51 also contains the following sentence: "Measures taken by Members in the exercise of this right of self-defense shall be immediately reported to the Security Council and shall not in any way affect the authority and responsibility of the Security Council under the present Charter to take at any time such action as it deems necessary in order to maintain or restore international peace and security."

${ }^{3}$ See, e.g., Brownlie, op. cit. supra note 1, at 264-80; Jessup, A MOdERN LAw of NATIONS 165.67 (1947); Kelsen, ThE LAW OF THE United NATIONS 269, 791-805 (1950); 2 OPPENHEIM, INTERNATIONAL LAW 153-59 (7th ed. Lauterpacht, 1952); Kunz, Individual and Collective Self-Defense in Article 51 of the Charter of the United Nations, 41 AM. J. INr'L LAw 872, 877-79 (1947). BROWNuIE, supra at 270-72, acknowledges that there is no indication in the San Francisco documents that the right of legitimate self-defense referred to by the Charter framers in connection with article 2 (4) was to be equated with the right referred to in article 51 , but he argues that "the general tendency was towards a restrictive interpretation of any permission in relation to the use of force," and that the San Francisco discussions of article 51 contain no indication "that the right of self-defense in the Article was in contrast with any other right of self-defense permitted by the Charter or that the phrase 'if an armed attack occurs' was anything other than a characterization of the right of self-defense."

- The Act of Chapultepec declares that "every attack of a State against ... an American State, shall ... be considered as an act of aggression against the other States which sign this Act." Final Act of the Inter-American Conference on Problems of War and Peace, Mexico City, March 8, 1945, 60 Stat. 1831, 1839, T.I.A.S. No. 1543.

- See note 3 supra and text accompanying note 52 infra.

- See e.g., Bowetr, op. cit. supra note 1, at 182-99; BrierLy, The LAw of Nations 417-21 (6th ed. Waldock, 1963); Seligman, The Legality of U.S. Quarantine Action 
The two views just mentioned represent polar positions on the relationship between the Charter and the right to use force in selfdefense. On the broader question of whether unilateral use of force may be permissible in circumstances not amounting to selfdefense, some scholars hold the view that the only force prohibited by the Charter is force falling within one of the three categories named in article 2 (4). This view of article 2 (4) is not inconsistent with a self-defense approach which would accept the "armed attack" language of article 51 as a limit on the right to use force in selfdefense. ${ }^{7}$

A third view of the Charter and self-defense holds that even if "armed attack" is accepted as a limit on the right to use force in selfdefense, ${ }^{8}$ the interpretation of that language must expand with the times if self-defense is to provide any meaningful protection. Proponents of this view point variously to increasing emphasis on subversion and on "wars of liberation," and to the development of nuclear weapons, ballistic missiles and Polaris submarines. ${ }^{\natural}$

A fourth view, related to the third, but having even less contact with the language of the Charter, would emphasize the need to view

Under the United Nations Charter, 49 A.B.A.J. 142 (1963); Larson, Letter to N.X. Times, Nov. 12, 1962, p. 28, col. 5 .

7 See, e.g., Stone, AGgression ANd Wordd Order 94-98 (1958). See also Dahm, Das Verbot der Gewaltanwendung nach Art. 2(4) der UNO-Charta und die Selbsthilfe gegenüber Völkerrechtsverletzungen, die keinen bewaffneten Angriff enthalten, 11 JAHRBUCH FÜR INT'LES RECHT 48 (1962).

"It may also be argued that "armed attack" is the equivalent of "armed aggression." Article 51 was included in the Charter largely to account for collective defense under the Act of Chapultepec, note 4 supra, which appears to equate "attack" with "aggression." Moreover, the French text of article 51 uses the term "aggression armee," rather than "attaque armée," although the Chinese, Russian and Spanish texts use equivalents of the English term "armed attack." See 59 Stat. 1044 (English), 1076 (French), 1106 (Chinese), 1136 (Russian) and 1168 (Spanish). All five texts are "cqually authentic," U.N. CharTer art. 11l. This discrepancy was not noticed at San Francisco, or, indeed, by early writers. Sce, e.g., KELSEN, op. cit. supra note 3, at 797-98; Kunz, op. cit. supra note 3.

- See, e.g., Singh, Nuclear Weapons and Internationar Law 126-30 (1959); McDevitt, The UN Charter and the Cuban Quarantine, I7 JAG J. 71, 79.80 (1963); Waldock, The Regulation of the Use of Force by Individual States in International Law, 81 HAGue Academy INT'L LAw, RecueIL des Cours 451, 495-505 (1952). Other writers regard the new weapons as reaffirming the nced for the comparatively clear and objective test of "armed attack." See, e.g., Henkin, Force, Intervention and Neutrality in Contemporary International Law, 57 Proc. AM. Soc. INT'L LAW (1963). In 1956 Professor Röling, the Netherlands representative on the U.N. Special Committee on the Question of Defining Aggression, proposed to define "armed attack" as used in article 51 as "any use of armed force which leaves the State against which it is directed no means other than military means to preserve its territorial integrity or political independence. ..." U.N. GEN. Ass. OFF. RF.c. 12th Sess., Supp. No. 16, at 25 (A/3574) (1957). See also Stone, Aggression AND WorLd ORDER $72-76$ (1958). 
international law as a comprehensive system, embracing all acts, events and security requirements, and assert that the "lawfulness" of an act is determined by inquiring into its "reasonableness in particular context." This approach would develop, out of whole cloth, as it were, a set of factors to be analyzed in each case as a test of reasonableness. The criteria suggested for self-defense include, for example, whether the state claiming self-defense seeks to conserve existing values or to extend them or to destroy other values, and whether the state against which force is exercised in self-defense has "aggressive characteristics." 10 The "armed attack" language of article 51 may be treated under this approach either as a special case in the manner of the second view, or as an expandable term in the manner of the third view.

Feelings run high on all sides of the self-defense issue. At the 1963 annual meeting of the American Society of International Law, for example, some speakers expressed the view in the course of several discussions centering on the Cuban quarantine, ${ }^{11}$ that international law would become irrelevant, or would demonstrate its irrelevancy, if it did not allow for the acts necessary to assure the continued existence of states. "Armed attack," it was argued, is no longer a realistic limit on resort to force in self-defense, if, indeed, that limit ever was realistic or in fact accepted by states. Other speakers argued that basing the legality of the quarantine on selfdefense would inexorably lead to the destruction of existing legal barriers to preemptive and preventive war. Undermining the "armed attack" criterion, it was intimated, would open a Pandora's Box of aggression, with every use of force sought to be justified as legitimate self-defense.

No resolution of the self-defense issue is in sight. Governments, for the most part, have not taken firm positions one way or the other,

\footnotetext{
${ }^{10}$ Mallison, Limited Naval Blockade or Quarantine-Interdiction: National and Gollective Defense Claims Valid Under International Law, 31 Geo. WAst. L. REv. 335, 355.60 (1962), based on McDougal \& Feliciano, op. cit. supra note I, at 217-44. The quotations are from McDougal \& Felrciano at 218, and Mallison at 359, respectively. Mallison points out that the U.S. "national objective ... of protecting and maintaining existing values may be contrasted with that of the Soviet Union in extending its power by using military force." Mallison, supra at 358 .

${ }_{11}$ The proceedings of the 1963 annual meeting are not available at this writing, and it therefore would not be appropriate to identify specific speakers with specific statements. The program included two panel discussions of legal issues related to the quarantine, one chaired by Arthur Larson, with Richard J. Barnet, Abram Chayes, Dean Acheson and Quincy Wright as panelists, and the other chaired by Milton Katz, with Louis Henkin as panelist and Myres S. McDougal, Charles M. Spofford and Eli Whitney Debevoise as commentators.
} 
and there has been no indication that a judicial determination would be acceptable. Much of the language used in self-defense treaties ${ }^{12}$ can be viewed as not inconsistent with either polar position on the role of article 51, and United Nations practice, which is confined largely to positions taken by states, is inconclusive and gives some support to each of the above approaches. ${ }^{13}$

This article will not undertake to demonstrate that one or another of the views outlined above must be accepted. ${ }^{14}$ The purpose here, rather, is to ask, first, whether the Cuban quarantine may be viewed as self-defense under any theory, and if so, whether the facts of the quarantine lend support to any particular self-defense theory. A second and more important question, on the assumption that the quarantine may serve as precedent for self-defense, is whether the facts provide any new limits on the right to use force in self-defense. Has the quarantine destroyed all legal barriers to disguising aggression as self-defense? Can we develop realistic and workable limits for self-defense on the basis of the quarantine?

\section{II}

\section{The Quarantine and Self-Defense: Official Views}

There has so far been little in the way of legal analysis on the part of any state. Soviet statements have been limited to general and blanket condemnations of the quarantine as violating numerous articles of the U.N. Charter and to assertions that the quarantine

\footnotetext{
12 The collective defense treaties entered into by the United States are framed in terms of "armed attack," but do not firmly establish "armed attack" as a limit on the right to use force in self-defense. Both the NATO and the Rio Treaties, for example, refer to the "right of individual or collective self-defense recognized" by U.N. CHARTER art. 51, but do not exclude force in other cases. North Atlantic Treaty, April 4, 1949, arts. 4-5, 63 Stat. 2241, 2242-44, T.X.A.S. No. 1964; Inter-American Treaty of Reciprocal Assistance, Sept. 2, 1947, arts. 3, 6, 62 Stat. 1681, 1700, T.I.A.S. No. 1838 [hereinafter cited as Rio Treaty]. See text at note 24 infra. The Warsaw Pact also refers to "armed attack," and speaks of exercising the right of self-defense "in accordance with" U.N. Charter art. 51, without, however, limiting possible uses of force in self-defense to cases of "armed attack." Treaty of Friendship, Co-operation and Mutual Assistance, May 14, 1955, arts. 3, 4, 219 U.N. Treaty Series 3, 28.

${ }^{13}$ See Higgins, The Legal Limits to the Use of Force by Sovereign States: United Nations Practice, I961 BRIT. YB. INT'L L. 269, 297-308 (1962).

14 Professor Covey Oliver has aptly commented that "the temptation to label" the Cuban quarantine in terms of a particular doctrine ought to be avoided, and that "pro. ponents of international law and order cannot now and on the basis of the present record say with the assurance of absolute credibility that the resolution of the [Cuban] crisis was an unquahified triumph for the law of the Charters [of the U.N. and of the OAS] or for any particular legal outlook, theory, or doctrine." Oliver, International Law and the Quarantine of Cuba: A Hopeful Prescription for Legal Writing, 57 AM. J. INT'L L. 373, 375 (1963).
} 
was "aggression" and "piracy."15 United States statements, 16 from the President's quarantine speech through statements made in the Security Council and in the Organization of American States (OAS), also contain little in the way of legal analysis. The main legal arguments advanced on behalf of the United States appear in two brief comments by Abram Chayes, legal adviser to the Department of State. ${ }^{17}$

The Chayes statements seek to justify the quarantine as a regional collective security measure undertaken pursuant to a recommendation of the OAS, which is the regional organization having jurisdiction of the premises. ${ }^{18}$ Both statements minimize the role of self-defense. In the first statement, although Mr. Chayes points out that the quarantine "was designed to deal with an imminent threat to our security," he appears to conclude that the quarantine was not self-defense. He states, in fact, that the President "in his speech did not invoke article 51 or the right of self-defense."19 To the extent that this statement would place the quarantine entirely outside of

${ }^{16}$ See debate in the Security Council, Oct. 24-25, 1962, U.N. Docs. Nos. S/PV. 1022-1025 (1962); Embassy of the U.S.S.R., Press Release No. 110 (Oct. 23, 1962); Letter from the U.S.S.R. to the President of the Security Council, U.N. Doc. No. S/5186 (Oct. 23, 1962). Professor Korovin has charged that the quarantine violated the U.N. Charter obligation to "live together in peace with one another as good neighbors" (Preamble), and the obligations assumed under article 1, paragraph 2, and article 2, paragraphs 1, 3, 4 \& 7. Korovin, International Law Through the Pentagon's Prism, 1962 INT'L AfraIRs (Moscow), No. 12, p. 3, 6 (Dec. 1962). Ghana was the only state to give even a brief legal analysis in the Security Council debate. Ghana's view was that "the measures which any State takes to preserve its own security are entirely a matter for its judgment," and that the quarantine cannot be justified as self-defense because "incontrovertible proof is not yet available as to the offensive character of military developments in Cuba." U.N. Doc. No. S/PV. 1024, at 48-51 (Oct. 24, 1962). U.S. Ambassador Stevenson later presented proof in the form of aerial photographs, but the representative of Ghana did not again comment on the state of proof as to the "offensive character of military developments in Cuba." U.N. Doc. No. S/PV. 1025, at 47-51 (Oct. 25, 1962).

${ }^{10}$ United States statements are collected at 47 DEP'T STATE BuLL. 715-47 (No. 1220, Nov. 12, 1962) [hereinafter cited as DSB].

${ }^{17}$ Chayes, The Legal Case for U.S. Action on Cuba, Dep't State Press Release 660, Nov. 3, 1962, 47 DSB 763; Chayes, Law and the Quarantine of Cuba, 41 Foreign AFFAIRS 550 (1963).

${ }^{18}$ The OAS resolution, OAS Doc. No. OEA/Ser.G/V, G-d-1024/Rev. 2 (Oct. 23, 1962), adopted by the OAS Council acting provisionally as the Organ of Consultation under the Rio Treaty, supra note 12, appears at 47 DSB 722-23, and is quoted in the text at notes 34,35 infra. For a discussion of the regional collective security theory, see McDevitt, supra note 9, at 71-75; The INTER-American System aNd THE Cubá Crists (Fammarskjold Forum No. 3, Tondel ed. 1963).

${ }^{10} 47$ DSB 764. The President said in his speech that the steps ordered by him were taken "in defense of our own security and of the entire Western Hemisphere." 47 DSB 716. The quarantine proclamation uses the expression "to defend the security of the United State." Proclamation No. 3504, 27 Fed. Reg. 10401; 47 DSB 717 (1962). 
the self-defense context, it has been modified by the second statement, which includes the following:

The Charter obligation to refrain from the use of force is not absolute. Article 51, of course, affirms that nothing in the Charter impairs "the inherent right of individual or collective self-defense." The quarantine was defensive in character and was directed against a threat to the peace. But neither the President in his speech nor the O.A.S. in its resolution invoked Article 51.20

If the quarantine is "defensive in character" but not based on article 51 , this at least implies that a right to use force in self-defense may exist outside of article 51 . The Chayes regional collective security theory makes quite clear, however, that the quarantine is not to be regarded as unilateral action whether in self-defense or otherwise. Mr. Chayes pointed out that self-defense "is not the only justifiable use of force" under the U.N. Charter, and that U.N. members permit the United Nations itself to "sanction the use of force to deal with a threat to the peace" for the following reasons:

First, all the members have constituted the United Nations for these purposes [i.e. dealing with threats to the peace]. In signing the charter they have assented to its [United Nation's] powers and procedures. Second, the political processes by which the U.N. makes a decision to use force give some assurance that the decision will not be rashly taken.21

Mr. Chayes then draws a parallel to the OAS, arguing that "the same two factors [would] legitimize use of force in accordance with the OAS resolution dealing with a threat to the peace in the hemisphere." Cuba had assented to OAS powers and procedures by becoming, and remaining, a party to the Rio Treaty, even though a recent OAS decision had declared that "the present government of Cuba has voluntarily placed itself outside the inter-American system" as a consequence of repeated acts contrary to inter-American principles. $^{22}$ The second factor, an OAS safeguard to rash action, was demonstrated by "the fact that, despite the disproportion of power between the United States and its neighbors to the south, it

${ }^{20} 41$ ForEIGN AFFAIRs at 553-54.

2147 DSB 765.

${ }^{22}$ Res. VI, Exclusion of the Present Government of Cuba From Participation in the Inter-American System, 8th Meeting of Consultation of Ministers of Foreign Affairs, Punta del Este, Jan. 22-31, 1962, 46 DSB 281 (1962). The vote was 14 to 1 (Cuba), with 6 abstentions (Argentina, Bolivia, Brazil, Chile, Ecuador, Mexico). See also note 47 infra. Cuba was not represented at the OAS meeting which adopted the quarantine resolution, note 18 supra. 
was not until the danger was clear and present that the necessary majority could be mustered to sanction use of armed force." 23

The official United States view, it may be concluded, does not exclude collective self-defense as a possible legal basis for the quarantine, even though the legality of the quarantine is expressed in terms of regional collective action. These statements do make clear, however, that the United States does not wish to invoke the right to use force in self-defense as the right is described in article 51 of the Charter. And, in view of the procedure followed in the OAS, it seems clear that the quarantine was thought by all OAS members to fall outside of article 51. In taking its case to the OAS, the United States cited article 6 of the Rio Treaty, which deals with "aggression which is not an armed attack," rather than article 3 of that treaty, which provides for collective self-defense in the event of "an armed attack by any State against an American State." Article 3 of the Rio Treaty refers to "the inherent right of individual or collective selfdefense recognized by Article 51" of the U.N. Charter. The OAS quarantine resolution quotes the entire text of article 6 of the Rio Treaty, and does not mention article $3 .^{24}$

The clarity with which the procedures followed in the OAS set article 51 self-defense aside, however, does not foreclose development of a self-defense approach outside of article 51 of the U.N. Charter. Reliance on article 6 of the Rio Treaty does not preclude a selfdefense approach because article 6 calls both for measures "for the common defense" and for measures "for the maintenance of the peace and security of the Continent."25 The OAS resolution is based on article 6 , but does not make clear whether the measures recommended were for one or the other, or for both, of the two purposes.

Even assuming that the initiators of the quarantine sought to

2347 DSB 765.

24 See note 18 supra. Article 6 of the Rio Treaty provides as follows: "If the inviolability or the integrity of the territory or the sovereignty or political independence of any American State should be affected by an aggression which is not an armed attack ... or by any other fact or situation that might endanger the peace of America, the Organ of Consultation shall meet immediately in order to agree on the measures which must be taken in case of aggression to assist the victim of the aggression or, in any case, the measures which should be taken for the common defense and for the maintenance of the peace and security of the Continent." Article 8 provides that the measures which may be agreed upon by the Organ of Consultation include "partial or complete interruption of economic relations . . . and use of armed force."

${ }^{25}$ See note 24 supra. The U.S. letter requesting convocation of the OAS Organ of Consultation looked toward the immediate adoption by that Organ of "appropriate measures for the common defense." OAS Doc. No. OEA/Ser.G/II, C-a-462, at 2 (Oct. 23, 1962). 
classify the action as a regional collective security measure rather than as self-defense, it may be doubted whether such an attempt could prevent future use of the quarantine as precedent for resort to force in self-defense. The U.N. took no decision as to the legality or legal basis of the quarantine and, if the quarantine is regarded as a permissible use of force, there would appear to be nothing to prevent some future protagonist from constructing legal arguments based on what actually happened in the quarantine, rather than on the legal form sought to be given those events by the actors.

A similar argument may apply to the effect of the demonstrated intent to place the quarantine outside the article 51 concept of selfdefense; this intent may not prevent future use of the quarantine as precedent in the expansion of the article 51 term "armed attack." Assuming that the quarantine will be regarded as having been a permissible use of force, perhaps future actors may still argue that it could have been legal only under an expanded view of the article 51 term "armed attack." 26

One may conclude, then, that even if the American republics refrain from raising self-defense as a legal basis for the quarantine, the seeds of this theory have been sown by the action actually taken, ${ }^{27}$ and the implications of the quarantine cannot be limited merely by asserting that a particular legal theory was not contemplated.

\section{III}

\section{The Facts}

Having concluded that despite United States official pronounce; ments the Cuban quarantine will have an impact on the law of

\footnotetext{
${ }^{20}$ The OAS resolution, note 18 supra, being based on article 6 of the Rio Treaty, note 24 supra, stands as an OAS decision that, in so far as the Rio Treaty is concerned, the acts countered by the quarantine amounted to "an aggression which is not an armed attack." It may be argued, however, that the interpretation of the term "armed attack" as used in the Rio Treaty is a matter for the OAS, and need not coincide with interpretations given identical language used in the U.N. Charter. The reverse of this proposition is even more clearly true in view of the fact that, while all OAS members are also U.N. members, the OAS members form only a small minority of the U.N. membership.

${ }^{27}$ Israeli government officials have recently expressed alarm that the Arab Federation between Egypt, Syria and Iraq would absorb Jordan and thereby gain access to Israel's eastern frontier. This development "in the words of an Israeli newspaper that reflects the Government view, 'would not be the internal affair of Jordan any more than the placing of Soviet rockets on Cuban soil was the [internal] affair' of Cuba." Blair, Israel Wants U.S. to Adopt Harder Line on Nasser Expansionism, N.Y. Times, April 25, 1963, p. 3, cols. 4, 8. The implication is that an Arab Federation takcover of Jordan would permit a defensive response by Israel.
} 
self-defense, the next question is what that impact will be, and how it can be limited. Before reaching that question, however, it is necessary to examine the facts leading up to and surrounding the quarantine, taking into account the legal procedures followed, as well as official statements concerning the factual basis for the action taken.

The starting point in an examination of the facts is President Kennedy's radio and television address of October 22, 1962. In that speech the President stated that the "quarantine on all offensive military equipment under shipment to Cuba is being initiated."28 The President's Proclamation ${ }^{29}$ actually instituting the quarantine was not signed, however, until 7:06 p.m. on October 23, well after the OAS Organ of Consultation had acted to recommend that OAS members "take all measures, individually and collectively, including the use of armed force," to prevent Soviet "military material and related supplies which may threaten the peace and security of the Continent" from reaching Cuba. ${ }^{30}$ The quarantine proclamation makes specific reference to the OAS resolution, and it is clear, therefore, that the OAS resolution forms part of the factual background against which the United States acted. In this sense, then, the quarantine was not unilateral action. ${ }^{31}$

The President's address of October 22 began with the announcement that United States surveillance of Cuba had disclosed that Soviet "offensive missile sites" were being constructed in Cuba. "The purpose of these bases," said the President, "can be none other than to provide a nuclear strike capability against the Western Hemisphere." The Soviet missiles being shipped to Cuba were

\footnotetext{
${ }^{28}$ The President's speech appears at 47 DSB 715-20. The quotation is from 47 DSB 716 (Emphasis added.)

${ }_{20}$ President Kennedy wrote the exact time underneath his signature. The quarantine began at 2:00 p.m. Greenwich time, October 24, 1962. Proclamation No. 3504, 27 Fed. Reg. 10401 (1962), 47 DSB 717. It ended at 11:00 p.m. Greenwich time, November 20, 1962. Proclamation No. 3507, 27 Fed. Reg. 11525 (1962), 47 DSB 918.

${ }^{30}$ See note 18 supra. The main operative paragraph of the OAS resolution is quoted in the text at note 35 infra.

${ }^{32}$ Other OAS members in fact participated in the quarantine. Within one week of the President's speech, Costa Rica, the Dominican Republic, Guatemala, Haiti, and Honduras had placed port facilities at the disposal of the U.S. quarantine forces, and on October 27, Argentina supplied two destroyers for quarantine duty. On November 9, 1962, the United States, Argentina and the Dominican Republic established a "Combined Quarantine Force" pursuant to an OAS recommendation of November 5, 1962, that the "states participating with military forces or with other facilities in the defense of the Hemisphere work out directly among themselves the technical measures that may be necessary to the co-ordinated and effective action of the combined forces . ..." U.N. Docs. Nos. S/5202, S/5206, S/5208 (1962).
} 
"large, long-range, and clearly offensive weapons of sudden mass destruction." Furthermore, said the President, the missile sites were being constructed swiftly and secretly and in violation of repeated Soviet assurances "that the arms buildup in Cuba would retain its original defensive character and that the Soviet Union had no need or desire to station strategic missiles on the territory of any other nation." 32

Perhaps the most significant point made by the President was that the "sudden, clandestine decision to station strategic weapons for the first time outside of Soviet soil-is a deliberately provocative and unjustified change in the status quo which cannot be accepted" by the United States. The President stated that:

We no longer live in a world where only the actual firing of weapons represents a sufficient challenge to a nation's security to constitute maximum peril. Nuclear weapons are so destructive and ballistic missiles are so swift that any substantially increased possibility of their use or any sudden change in their deployment may well be regarded as a definite threat to peace.

For many years both the Soviet Union and the United States, recognizing this fact, have deployed strategic nuclear weapons with great care, never upsetting the precarious status quo which insured that these weapons would not be used in the absence of some vital challenge ....

The President asserted that Russia's "urgent transformation of Cuba into an important strategic base" constituted an "explicit threat to the peace and security of all the Americas" and that the Soviet action flagrantly and deliberately defied the "traditions of this nation and hemisphere," the Rio Treaty, and the Charter of the United Nations. ${ }^{33}$ The President noted, moreover, that:

the nations of Latin America have never previously been subjected to a potential nuclear threat.

The following day, October 23, 1962, the OAS Organ of Consulitation supported the President's view of the facts by adopting a resolution which recited that:

Incontrovertible evidence has appeared that the Government of Cuba, despite repeated warnings, has secretly endangered the peace of the Con-

${ }^{32} 47$ DSB 715. The President stated that a few days earlier Soviet Foreign Minister Gromyko had falsely assured the President "that Soviet assistance to Cuba, and I quote [Gromyko], 'pursued solely the purpose of contributing to the defense capabilities of Cuba' ... and that 'if it were otherwise,' Mr. Gromyko went on, 'the Soviet Covernment would never become involved in rendering such assistance." 47 DSB 716.

${ }^{33}$ The quotations are taken from $47 \mathrm{DSB} 715-16$. The President did not cite specific articles of the Rio Treaty or of the U.N. Charter alleged to have been violated. 
tinent by permitting the Sino-Soviet powers to have intermediate and middle-range missiles on its territory capable of carrying nuclear warheads ..... s4 $^{34}$

The United States quarantine action followed and implemented the OAS resolution just quoted, in which the presence in Cuba of Soviet missiles with nuclear capacity is found to be a threat to the peace, but operative paragraph 1 of the OAS resolution called for the "withdrawal from Cuba of all missiles and other weapons with any offensive capability." If "weapons with any offensive capability" means something other than nuclear weapons, then paragraph 1 of the OAS resolution would appear to go beyond the OAS finding just quoted. Operative paragraph 2 of the OAS resolution, which contains the OAS recommendations, is tied to the OAS finding, however. Paragraph 2 recommends that OAS members:

take all measures, individually and collectively, including the use of armed force, which they may deem necessary [1] to ensure that the Government of Cuba cannot continue to receive from the Sino-Soviet powers military material and related supplies which may threaten the peace and security of the Continent and [2] to prevent the missiles in Cuba with offensive capability from ever becoming an active threat to the peace and security of the Continent. ${ }^{35}$

The quarantine implemented only the first recommendation, numbered [1] above, of paragraph 2, and did so, in the language of the President's Proclamation, by interdicting "the delivery of offensive weapons and associated materiel to Cuba."36 The "prohibited materiel" was defined in the proclamation as follows:

34 47 DSB 723. The words "capable of carrying nuclear warheads" were added to the U.S. draft resolution as a result of debate in the OAS in which the representative of Uruguay, referring to the fact that nuclear weapons were a post-Charter development, stressed that the capacity of the Soviet missiles to deliver nuclear weapons was an essential element in the decision to be taken. Secretary Rusk agreed to accept the simple adjective "nuclear missiles," but the representative of El Salvador protested that it had not yet been incontrovertibly proven that the Soviet missiles were armed with nuclear weapons, and that, in any event, the missiles were a danger to small countries whether or not they actually carried nuclear warheads. The language originally suggested by Uruguay, "capable of carrying nuclear warheads," was included as acceptable to all sides. Argentina thereupon voiced its agreement with that language and with the resolution as a whole for the reason that events had brought a new situation to the Americas-the threat of nuclear attack. OAS Doc. No. OEA/Ser.G/II, C-a-463, at 11-12, 14-16 (Oct. 23, 1962). El Salvador was alone in suggesting that OAS action might be taken against non-nuclear Soviet "offensive weapons" in Cuba, and it may be concluded that the OAS resolution is based on a finding that the deployment of Soviet strategic nuclear weapons to Cuba had endangered the peace of the Americas.

35 47 DSB 723. (Emphasis added.) The OAS frequently uses the English word "Continent" as the equivalent of "Hemisphere."

${ }^{36}$ Proclamation No. 3504, note 29 supra. (Emphasis added.) 
Surface-to-surface missiles; bomber aircraft; bombs, air-to-surface rockets and guided missiles; warheads for any of the above weapons; mechanical or electronic equipment to support or operate the above items; and any other classes of materiel hereafter designated by the Secretary of Defense for the purpose of effectuating this Proclamation.

The foregoing review of the facts leads to several conclusions. First, the quarantine was not unilateral action by the United States. ${ }^{37}$ Second, although the President's main concern was apparently with the threat to the precarious status quo in nuclear striking forces posed by the deployment of Soviet nuclear missiles to the Western Hemisphere, he also expressed concern that Latin America was being brought for the first time under the Soviet nuclear gun. The OAS resolution, however, stressed only the latter point, namely concern over the introduction of a Soviet nuclear threat into Latin America. ${ }^{38}$ The implications of this distinction will be explored in the next section.

Third, it may be concluded that the term "offensive weapons" as used in the President's proclamation means strategic nuclear weapons and that the quarantine was limited to the exclusion of weapons with nuclear capacity. Both the President and the OAS, though for somewhat different reasons, defined the threat against which quarantine action was taken as a threat posed by the presence of Soviet nuclear striking forces in the Western Hemisphere. The first recommendation of operative paragraph 2 of the OAS resolution, quoted above, makes specific reference to the OAS finding that peace had been endangered by Soviet "missiles . . . capable of carrying nuclear warheads." This basic OAS finding certainly confines the OAS recommendation to measures designed to exclude strategic nuclear weapons, if not to nuclear missiles, and considering that the United States quarantine action was explicitly founded on the OAS recommendation, the OAS limit must also apply to the action taken

\footnotetext{
${ }^{37}$ See note 31 \& text accompanying notes $28-31$ supra.

${ }^{38}$ See note 47 infra. The President's speech is directed at the Soviet Union, charg. ing that the U.S.S.R. had threatened the peace by shipping strategic nuclear missiles to Cuba, whereas the OAS resolution charges the Government of Cuba with secretly endangering the peace by "permitting" the emplacement of the Soviet missiles on Cuban soil. The difference in emphasis may perhaps be accounted for by a desire to maintain a posture that the OAS acted only with regard to a Hemisphere problem, altlough clearly the United States' motivation as expressed by the President arose out of the world-wide context of conflict with the Soviet Union. U.N. CHARTER art. 52(1) provides: "Nothing in the present Charter precludes the existence of regional arrangements or agencies for dealing with such matters relating to the maintenance of international peace and security as are appropriate for regional action ...." (Emphasis added.)
} 
by the United States. No move was in fact made by the quarantine forces to exclude anything other than Soviet strategic weapons systems with nuclear capacity.

Finally, as noted in the last section, the fact that the OAS acted under article 6 of the Rio Treaty, which deals specifically with "aggression which is not an armed attack," makes plain that the members of the OAS did not regard the Soviet action as an "armed attack" against the countries of the Western Hemisphere within the meaning of the Rio Treaty.

\section{IV}

\section{INTERPRETING THE FACTS}

As we have seen, the United States has not sought to rely on a self-defense argument, but that restraint may not prevent others from invoking the quarantine as precedent for use of force in self-defense. The facts demonstrate, however, that the Soviet action sought to be countered by the quarantine was not regarded as an "armed attack," and it would therefore be difficult, although perhaps not impossible, to use the facts of the quarantine as precedent for the expansion of the article 51 right to use force in self-defense against "armed attack."

Both the President and the OAS concluded that Cuba and the Soviet Union had threatened the peace by introducing a nuclear threat swiftly and secretly into the Western Hemisphere. The implication was that the secret and swift buildup of a significant Soviet nuclear capacity in Cuba could not be defensive and therefore could have as its purpose only the threatening of both the United States and Latin America with nuclear bombardment. In a self-defense context, the argument would be, in effect, that Soviet strategic missiles in Cuba constitute a "threat . . . of force against the territorial integrity or political independence" of the American republics in violation of U.N. Charter article 2 (4). If a threat of force under the circumstances of the Cuban crisis is to be regarded as giving rise to a right to act in self-defense, the question becomes: what, precisely, was the nature of the threat presented by Soviet nuclear missiles in Cuba, and will the nature of that threat limit the precedent value of the quarantine?

The approach taken here assumes that under some circumstances defensive force may be used even if no "armed attack" has occurred within the meaning of article 51 of the Charter, and that, apart from certain Charter limits discussed in the next section, the circumstances 
under which force may be used in self-defense are to be sought in general international law. The discussion here will be confined, however, to the impact of the quarantine on the development of the law of self-defense on the assumption that the quarantine is regarded as a permissible use of force. This paper will not attempt to set out and analyze the requirements for self-defense under general international law, or to demonstrate that the quarantine falls within those requirements. It is sufficient here to note that the right of selfdefense under general international law has been termed "as vague as it is unquestioned, and as liable to abuse in its application as it is indispensable in the present phase of the international society." 30

Some analysts have sought to define the threat countered by the quarantine as a threat that the Soviet Guban-based missiles would upset the balance between United States and Soviet strategic striking capacity. ${ }^{40}$ The President's words may perhaps be given that mean-

\footnotetext{
${ }^{39}$ Stone, Legal Controls of International Conflict 243.44 (1959). For extended discussions of the right of self-defense under general international law, see, e.g., Bowetr, op. cit. supra note 1, at 3-114; McDougal \& Feliciano, op. cit. supra note 1, at 207-53; Green, Armed Conflict, War, and Self-Defense, 6 ArCHiv Des VölkerRechTs 387 (1956/57); Schwarzenberger, Report on Some Aspects of the Principle of Self-Defense, INT'L LAw Ass'N, REPORT OF THE 48TH CONF., NEw YoRk, 1958, at 550, 566.89 (1959); Weightman, Self-Defense in International Law, 37 VA. L. REv. 1095 (1951). The following writers conclude that the Cuban quarantine was a permissible use of force in sclf-defense under general international law: Mallison, supra note 10; McDevitt, supra note 9; Seligman, supra note 6. See also Oliver, supra note 14. Henkin, supra note 9 , suggests that a case for the quarantine might be based on U.N. CIIARTER arts. 2 (4) and 52-54, but doubts that the quarantine conforms to the general international law requirements of self-defense for the reason that no one could say with any confidence or plausibility that the Soviet missiles in Cuba would ever be used against the United States, or against any other state. Henkin considers that the tradi. tional notion of self-defense is embodied in the 1841 statement of Secretary of State Webster in the Caroline case, [later adopted in the Nürnberg Judgment, see 41 AM. J. INr'L LAW 172, 205 (1947)] that the "inviolable character of the territory of independent states is the most essential foundation of civilization" and that exceptions to that principle on grounds of self-defense "should be confined to cases in which the 'necessity of that self-defense is instant, overwhelming, and leaving no choice of means, and no moment for deliberation." 2 MOORE, A Digest OF INTERNATIONAL LAw 412 (1906). Mallison, supra note 10, at 348, comments that the Caroline "formulation was probably unrealistically restrictive when stated in 1841," and that with today's weapons, "Secretary Webster's formulation could result in national suicide if it actually were applied instead of merely repeated."

to See, e.g., Crane, The Cuban Crisis: A Stratcgic Analysis of American and Soviet Policy, 6 ORBIs 528, 536-37 (1963). Crane's argument is that "a Soviet first strike from the USSR and Cuba on the American strategic weapons in the continental Unitcd States and overseas might have radically reduced the American deterrent force and convinced Soviet planners that the Soviet Union would be free to complete its conquest of the world by local war and nuclear blackmail." Id. at 537. Mallison, supra note 10, at 359 , states that if successful, the Soviet action "would have an immediate and drastic impact in changing the pre-existing relative military power of the Sovict Union and the United States."
} 
ing, but it is not clear that they must have that meaning either as regards the U.S.-U.S.S.R. military balance ${ }^{41}$ or as regards the legal basis for the quarantine. In a television interview on November 11, 1962, for example, Deputy Secretary of Defense Roswell Gilpatric stated that the Soviet Union has missiles capable of reaching the United States from Soviet territory and from submarines, and that therefore there had been no "major change in the overall military equation" between the Soviets and the United States as a result of the deployment of Soviet missiles to Cuba, although that deployment "changed the juxtaposition of these arrays of power" and was a great danger to the United States. Gilpatric stressed, however, that the Cuban buildup was "the first time the Soviets had ever put any such weapons outside their own immediate territory" and that "the effect on the Latin American countries as well as on ourselves in the Western Hemisphere was very destabilizing." 42

A theory which would utilize the threat to the status quo in strategic striking power as the legal basis for the quarantine would seem to have broad and unforeseeable implications. For example, could the Soviet Union make the same argument vis-à-vis any of the NATO nuclear force proposals? ${ }^{43}$ Or, would deployment of a large number of Polaris submarines into a new area upset the strategic status quo? And, why would the argument be limited to the deployment of nuclear weapons outside of national boundaries? Would it not

\footnotetext{
"1 See, e.g., London Institute for Strategic Studies, The Communist Bloc and the Western Alliances, The Military Balance, $1962-63$ (1962), 109 Cong. REc. 393-414 (Daily ed. No. 5, Jan. 16, 1963). The estimate was 438 land-based and Polaris ICBM's for the U.S., to 75 for the U.S.S.R. by the end of 1962. See also Brower, Nuclear Strategy of the Kennedy Administration, 18 Bull. Atomic Scientusts 34 (Oct. 1962); excerpts from Secretary of Defense McNamara's testimony before the House Armed Services Committee on Jan. 30, 1963, in Feld, McNamara on Strategy: A Change in Policy?, 19 Bull. Atomic Scirntists 36 (April, 1963).

62 The transcirpt of the Gilpatric interview is printed at 109 Cong. Rec. 2097, 2098-99 (daily ed. No. 21, Feb. 11, 1963). Gilpatric mentioned the "much shorter warning period" resulting from emplacement of the missiles in Cuba, but stated that "I don't believe that we were under any greater threat from the Soviet Union's power taken in its totality after this than we were before." Id. at 2099.

${ }^{43}$ In April, and again in May, 1963, the Soviet Union sent notes to Washington, London and Bonn objecting to the NATO nuclear force and reportedly warning that its creation might cause the Soviet Union to supply nuclear weapons to Warsaw Pact countries. The U.S. answer commented that the Soviet note "seems to imply that only the Soviet Union has the right to build up ... its nuclear strength," and asserted that the NATO measures were necessary in self-defense because Europe was within striking distance of hundreds of Soviet medium range missiles. N.Y. Times, April 10, 1963, p. 1, col. 8; id., May 19, 1963, p. 2, col. 1. Under the analysis developed below, the purpose for which strategic missiles are to be used would serve to distinguish the emplacement of U.S. missiles in NATO countries from the deployment of Soviet missiles to Cuba. See notes 45,50 and text accompanying note 50 infra.
} 
logically also extend to a "sudden" decision to procure large numbers of ICBM's even if those missiles were not to be emplaced abroad?

It will be recalled that the President spoke of the "precarious status quo" in terms of the deployment of nuclear missiles, stressing that a "sudden change in their deployment may well be regarded as a definite threat to the peace." 44 No doubt the sudden deployment to Cuba of a significant Soviet nuclear striking force posed a threat to the United States in terms of the over-all strategic balance, but it is not clear that this characterization of the threat must serve as the legal basis for the quarantine. The President noted the "potential nuclear threat" to which Latin America was being subjected for the first time, ${ }^{45}$ and, as has been pointed out, ${ }^{46}$ the United States took no unilateral action, but chose to act only through the OAS and pursuant to the OAS recommendation. Regardless, therefore, of whether the United States might lawfully have acted unilaterally on the basis of the Soviet threat to the over-all strategic status quo, it may be argued that the quarantine action actually taken rests on the OAS recommendation and that the precedent set by the quarantine may be limited accordingly.

The OAS resolution found that the introduction into Latin America of Soviet missiles capable of carrying nuclear warheads threatened the peace without reference to the U.S.-U.S.S.R. nuclear balance. ${ }^{47}$ It seems clear that the concern of the Latin American

\footnotetext{
44 See text following note 32 supra.

4s See text following note 33 supra. Ambassador Stevenson stated in the Security Council, 47 DSB 731, in distinguishing Soviet Cuban-based missiles from United States NATO-based missiles, that: "Missiles which help a country defend its independence, which leave the political institutions of the recipient countries intact, which are not designed to subvert the territorial integrity or political independence of other states, which are installed without concealment or deceit-assistance in this form and with these purposes is consistent with the principles of the United Nations. But missiles which introduce a nuclear threat into an area now free of it, which threaten the security and independence of defenseless neighboring states, which are installed by clandestine means, which result in the most formidable nuclear base in the world outside existing treaty systems-assistance in this form and with these purposes is radically different." (Emphasis added.)

${ }^{*}$ See note 31 , text at notes 28-31 supra.

"See notes 18, 34 \& text accompanying notes 34,35 supra. The OAS resolution quoted from Punta del Este Res. II, 46 DSB 279; and from a communiqué issued by an informal meeting of Ministers of Foreign Affairs of the American Republics, held at Washington, Oct. 2-3, 1962, 47 DSB 598. Punta del Este Res. II referred to the need to "counteract threats or acts of aggression, subversion, or other dangers to peace and security resulting from the continued intervention in this hemisphere of Sino-Soviet powers ...." The October statement called for paying "special and urgent attention to the situation created by the Marxist-Leninist regime in Cuba" and referred back to the Punta del Este resolution just quoted. The OAS emphasis, therefore, was on the
} 
states, as distinguished from the United States, was with maintaining a status quo in which Latin America has no nuclear missile bases and therefore does not face an immediate threat of nuclear war. ${ }^{48}$ In the sense that both United States and Soviet strategic missiles and bombers can reach every point on earth, no nation is entirely free of the threat of nuclear war, but there are areas, such as Africa, ${ }^{49}$ which have no nuclear bases and are not directly threatened with nuclear attack by any of the nuclear powers. Latin America was such an area prior to the Soviet deployment of nuclear weapons to Cuba, and, viewing the quarantine as OAS action, it may be concluded that the threat met by the quarantine was the threat of nuclear war in Latin America which would have resulted from the sudden and successful deployment of Soviet nuclear weapons to that area. So viewed, the precedent established by the quarantine may be put in terms of using force to counter the sudden introduction of nuclear weapons into an area formerly free of the direct threat of nuclear war, rather than using force to protect the balance between United States and Soviet strategic striking power.

Adopting a nuclear free area approach would avoid the ambiguities and broad implications of the strategic status quo approach. It would also render more meaningful the argument that the quarantine was multilateral action through the OAS, rather than unilateral action by the United States.

Furthermore, a focus on nuclear free areas clarifies the argument that the Soviet missiles were "offensive weapons." In the context of their shipment to an area previously free of a direct nuclear threat, the characterization of the Soviet weapons as "offensive weapons" means something more than that they have "offensive capability." Cuba claimed that the missiles were "defensive" and were needed to

dangers of Communist intervention buttressed by nuclear weapons, rather than on upsetting the strategic status quo.

${ }^{*}$ See note 34 supra. Following the quarantine action, Bolivia, Brazil, Chile and Ecuador proposed that the Latin American countries agree to establish Latin America as a denuclearized zone. See U.N. Docs. Nos. A/C.1/L.312/Rev.2 and A/5303/Add.1 (1962). On April 29, 1963, the Presidents of these four states, together with the President of Mexico, again called for making Latin America a denuclearized zone, declaring that they were "[d]eeply concerned over . . . the spread of nuclear weapons" and that they wished "to preserve their countries from the tragic consequences brought about by a nuclear war." U.N. Press Release SG/1479 (May 1, 1963).

to In 1961 the General Assembly called upon U.N. members to "consider and respect the continent of Africa as a denuclearized zone." General Assembly Res. 1652 (XVI), U.N. GeN. Ass. OFF. Rec. 16th Sess., Supp. No. 17, at 4 (A/5100) (1962). On April 15, 1963, the Soviet Union proposed that Africa should be made into an "atom-free zone." N.Y. Times, April 16, 1963, p. 1, col. 2. 
deter a United States invasion of Cuba, but the Cubans were given no control over the missiles and any credible retaliatory threat would still have to have been exerted by the Soviet Union. So far as the Soviet Union is concerned, however, that country declared that it was capable of exercising its nuclear deterrent threat against the United States without sending missiles to Cuba. The Soviet purpose in violating the nuclear free zone could, therefore, only be interpreted as posing an offensive threat against the United States and Latin America. The case of United States missiles in NATO countries must be distinguished on the grounds that the NATO countries, unlike Cuba, had already been subjected to a nuclear threat, and that missiles emplaced in response to a nuclear threat cannot be automatically classed as having an offensive purpose. ${ }^{50}$

The nuclear free area theory as it arises out of the Cuban quarantine is limited to the sudden deployment of a significant nuclear striking force to an area formerly free of the direct threat of nuclear war. The theory might, however, apply regardless of whether the sudden new nuclear threat was exerted by the outside power itself, or by an existing state in the area through the medium of nuclear weapons supplied by one of the nuclear powers. If the argument is extended to cases in which nuclear weapons are given to non-nuclear powers, the logical end result might be that the indigenous development of nuclear weapons by states not now facing a direct nuclear threat, such as, for example, the Chinese People's Republic, Japan or the United Arab Republic, would also constitute a threat to their neighbors that might justify an appropriate act of self-defense. The

\footnotetext{
${ }^{50}$ See notes 43,45 supra. Ambassador Stevenson stated in the Security Council that: "[U.S.] missile sites in NATO countries were established in response to missile sites in the Soviet Union directed at the NATO countries. The NATO states had every right and necessity to respond to the installation of these Soviet missiles by installing missiles of their own. These missiles were designed to deter a process of expansion already in progress. Fortunately, they have helped to do so." 47 DSB 731.

U.S. missiles were sent to NATO countries as a result of a 1957 decision of the NATO Heads of Government Conference that since the Soviet Union was introducing "the most modern and destructive weapons, including missiles of all kinds," into its armed forces, NATO had no alternative but to acquire intermediate range ballistic missiles. NATO Communiqué, Dec. 19, 1957, paras. 18-20, American Foreign Policy, Cunrent Documents, 1957, at 413, 418 (Dep't State Pub. No. 7101, 1961). By the end of 1962 , the U. S. had deployed 60 Thor missiles to Great Britain, 15 Jupiter missiles to Turkey and 30 Jupiter missiles to Italy. See 81 TiME, No. 5, p. 21 (Feb. 1, 1963). It was announced in January, 1963, however, that by agreement with the countries concerned, the U.S. would dismantle those missiles during the spring of 1963, and replace them with 8 Polaris submarines operating out of Holy Loch, and 6 Polaris submarines based in the Mediterranean. See ibid.; N.Y. Times, Jan. 18, p. 1, col. 2 (western ed.); id., Jan. 24, p. 1, col. 7; id., Feb. 13, p. 2, col. 8 .
} 
facts of the Cuban crisis, however, are limited to the swift and secret creation of a significant nuclear striking capacity, and the precedent thereby established might not extend to justifying a defensive response to the gradual proliferation of nuclear weapons.

The effort in this section has been to state the facts of the quarantine in such a way as to place limits on the precedent established by the quarantine when viewed as a use of force in self-defense. In Charter terms, the quarantine may be termed a defensive response to a threat of force, but viewing the quarantine as a permissible use of force need not result in the conclusion that every threat of force would justify a resort to force in self-defense. It has been suggested that the principle established by the quarantine may be limited to justifying as legitimate self-defense a multilateral response to the sudden deployment of a substantial nuclear striking force to an area which had formerly been free of the immediate threat of nuclear war. This limit as to the nature of the threat countered by the quarantine may have no meaning, however, if the world community lacks an effective procedural means of preventing future protagonists from expanding the precedent established by the quarantine, or by any other use of force, to suit their needs of the moment. The impact of the procedure followed in carrying out the quarantine is the subject of the next section.

\section{V}

\section{Procedural Limits}

The foregoing analysis suggests that the facts surrounding the quarantine may give rise to certain limits on the precedent value of the quarantine when viewed as a use of force in self-defense. The argument remains, however, that any breach in the wall of separation between the "objective criterion" of armed attack and the amorphous area of "aggression" will result in a flood of claims that uses of force under many and varied circumstances are justifiable as self-defense. This Pandora's Box argument is in part a reflection of the true state of the world, and therefore in part unanswerable except to question whether the availability of an involved legal argument makes resort to force more likely, but the beginnings of an answer may be sought through developing procedural limits on defensive uses of force.

The basic Charter limit on the use of force appears in article 2 (4). As has been noted, however, the framers of the Charter held the view that article 2 (4) did not impair or diminish the "right of 
self-defense against aggression." 51 The Committee which was responsible for drafting the Preamble, Purposes and Principles of the Charter reported with regard to article 2 (4) that:

The Committee wishes to state ... that the unilateral use of force or similar coercive measures is not authorized or admitted. The use of arms in legitimate self-defense remains admitted and unimpaired. The use of force, therefore, remains legitimate only to back up the decisions of the Organization at the start of a controversy or during its solution in the way that the Organization itself ordains. ${ }^{52}$

The Committee's view is internally consistent only if "legitimate self-defense" is thought of as limited to uses of force not inconsistent with collective measures undertaken by the world organization. Only then would it be possible to say both that the right of self-defense is "unimpaired" and that force is "legitimate only to back up the decisions of the Organization."

Article 2 (4) prohibits threats or uses of force "inconsistent with the Purposes of the United Nations," and the first Purpose of the United Nations stated in article $I$ is "to take effective collective measures for the prevention and removal of threats to the peace ...." It may therefore be argued that article 2 (4) imposes an obligation on states to refrain from using force unilaterally, even in self-defense, when their objectives can be accomplished by collective measures taken through the United Nations. "Self-defense," as an exception to the general rule against unilateral use of force, exists in the postCharter world only in situations with which the United Nations is unable to deal and in situations constituting an "armed attack" within the meaning of article 51. The suggested exhaustion of U.N. remedies rule does not apply in the latter case because article 51 saves an unqualified right of self-defense "if an armed attack occurs."

\footnotetext{
${ }^{61}$ Doc. No. 739, I/1/A/19(a), Report of Rapporteur of Subcommittee $1 / 1 / A$ to Committee 1/1, 6 U.N. CONF. INT'L ORG. Docs. 717, 721 (1945). The quoted language was included to explain the rejection of a Norwegian proposal which would amend article 2 (4) to prohibit all uses of force "not approved by the Security Council as a means of implementing the purposes of the Organization." Doc. No. 2, G/7 (n) (1), Amendments and Observations on the Dumbarton Oaks Proposals, Submitted by the Norwegian Delegation, 3 U.N. CoNF. INT'L ORG. Docs. 365, 366 (1945) (italics in orig. inal). The Rapporteur of Subcommittee I/1/A, supra, reported that the subcommittec considered the "sense of approval" proposed by Norway as "ambiguous, because it might mean approval before or after the use of force. It might thus curtail the right of states to use force in legitimate self-defense while it was clear to the subcommittee that the right of self-defense against aggression should not be impaired or diminished."

${ }^{52}$ Doc. No. 944, I/1/34 (1), Report of Rapporteur of Committee 1 to Commission I, 6 U.N. CONF. INT'L ORG. Docs. 446, 459 (1945). The quoted statement was the Committee's explanation of the rejection of the Norwegian proposal. See note 51 supra.
} 
Even that article, however, saves the right to use force only "until the Security Council has taken measures necessary to maintain international peace and security." 53 The suggested article 2 (4) limit goes beyond the article 51 limit because under the suggested analysis of article 2 (4), effective U.N. remedies would have to be exhausted before unilateral force may be used, and even when unilateral force is permissible, it may not be used to do things which can be done collectively through the United Nations. Under article 51 , however, unilateral force may be used straight-away to accomplish the whole purpose for which force may be used, unless supplanted by collective measures actually instituted by the United Nations.54 In this sense, then, even if defensive force is regarded as permissible outside of the article 51 case of "armed attack," such a use of force may be subject to a Charter limit derived from articles 2 (4) and 1 (1) in terms of procedures which must be followed.

The analysis suggested above may merely add a procedural dimension to the general international law concept of "proportionality and necessity" with regard to self-defense ${ }^{55}$ in the sense that where an effective and timely remedy is available through the United Nations, any unilateral use of force, or even force recommended by a regional organization, ${ }^{56}$ goes beyond the degree of force which is

${ }^{53}$ KELSEN, op. cit. supra note 3, at 802-03, suggests that article 51 was probably intended to give the Security Council the power to decide when the measures taken by it fulfill the condition stated in article 51 and therefore require the attacked state to end its defensive use of force, but that article 51 is at least ambiguous in this regard.

- BowETT, op. cit. supra note 1, at 269, concludes that self-defense "presupposes the absence of any alternative means of protection," but earher he treats the relationship between articles $2(4)$ and $1(1)$ as resulting in a procedural limit similar to that resulting from article 51. Bowett comments at 186 that "the Purposes [of the U.N.] envisage 'collective measures' whereas action in self-defence is primarily a unilateral measure undertaken on the state's own responsibility; but this objection loses force when self-defence is conceived as an interim means of protection, available until those collective measures ensure the same protection of the individual state's rights, a protective right rather than a collective sanction."

"c Brownlre, op. cit. supra note 1 , discusses the modern law of proportionality at 261-64, and special cases of necessity at 376-77. See also McDougal \& Feliciano, op. cit. supra note 1 , at 229-44. Kunz, supra note 3 , at 877 , suggests that "the conditions of necessity, reasonableness, and a certain proportionality, which the municipal law prescribes for the exercise of the right of self-defense, are lacking in Article 51." Contra, Mallison, supra note 10 , at 361 , n.118.

00 The Chayes argument, text at notes 21-23 supra, appears to treat "collective measures" as used in article $1(1)$ as meaning regional action as well as U.N. collective action. See AMr. BAR Ass'N, Washington Letter, Nov. 9, 1962, at 2 (said to reflect the views of the Office of the Legal Adviser, Dep't of State). This conflicts with the language of U.N. Charter art. 1 , as well as with article 53 (1), which provides that "no enforcement action shall be taken under regional arrangements or by regional agencies without the authorization of the Security Council ...." Chayes argues, however, that the "withering away of the Security Council" requires the development of other "peace- 
necessary to secure adequate protection. The suggested analysis would, however, tie self-defense more closely to the overriding Charter obligation to bring unsettled disputes to the United Nations. ${ }^{57}$ Except in cases of "armed attack," uses of force in selfdefense would be limited to acts necessary to preserve the possibility of obtaining effective protection through the United Nations. The state threatened or attacked must decide in the first instance whether and to what extent unilateral force is permissible, but, as pointed out below, that decision remains subject to review by the appropriate organ of the world organization.

Returning to the facts of the quarantine, the speed and secrecy with which Soviet missiles were being emplaced in Cuba gain new significance in terms of available remedies. Soviet efforts to conceal the missile shipments, and even to deny that the shipments had taken place, together with the speed with which the Soviet Union acted may be argued to have left no time in which to seek United Nations collective measures. In other words, by the time a United States or an OAS request for United Nations authorization of quarantine measures had been vetoed in the Security Council, as it surely would have been, and acted on by the General Assembly under the Unitingfor-Peace procedure, ${ }^{58}$ the Soviet Union would have accomplished its purpose of deploying a significant strategic nuclear capacity to Cuba. The threat thereby presented could not have been prevented by

keeping institutions," such as regional organizations, 47 DSB 765; and that a "narrowing process of interpretation" has confined "enforcement action" to a "rigorously narrow category," and construed the article $53(1)$ requirement of "authorization" as satisfied by subsequent action of the Security Council "or even by a mere 'taking note' of the acts of the regional organization." Chayes, Law and the Quarantine of Cuba, 41 FOREIGN AFFAIRS 550, 555-57 (1963).

${ }^{67}$ U.N. CharTer art. 37 (1) requires U.N. Members to refer disputes to the Security Council if peaceful settlement fails and if, in the words of article 33 (1), "the continuance of [the dispute] is likely to endanger the maintenance of international peace and security." See Wright, Power Politics or a Rule of Law?, 147 THE NEw Republic, No. 26, p. 11-12 (Dec. 29, 1962), for a view that the U.S. quarantine action disregarded the obligations of articles 33 and 37.

${ }^{5}{ }^{8}$ In 1950 the General Assembly resolved that "if the Security Council, because of lack of unanimity of the permanent members [i.e., the veto], fails to exercise its primary responsibility for the maintenance of international peace and security in any case where there appears to be a threat to the peace, breach of the peace, or act of aggression, the General Assembly shall consider the matter immediately with a view to making appro. priate recommendations to Members for collective measures, including in the case of a breach of the peace or act of aggression the use of armed force when necessary, to maintain or restore international peace and security." General Assembly Res، 377 A (V), U.N. Gen. Ass. OfF. Rec. 5th Sess., Supp. No. 20, at 10 (A/1775) (1950). The Uniting-for-Peace procedure was used in 1956 to establish UNEF, the U.N. Emergency Force in the Middle East. General Assembly Res. 998, 1000 (ES-1), U.N. GEN. Ass. OFF. Rec. 1st Emergency Sp. Sess., Supp. No. 1, at 2-3 (A/3354) (1956). 
action through the United Nations, and once the Soviet nuclear threat had been established, it would have become incomparably more difficult, if not impossible without a major war, to secure the removal of that threat through the United Nations or otherwise.

For these reasons, then, the available United Nations collective measures could not have effectively halted the inflow of strategic weapons, and it was therefore not inconsistent with the collective measures "Purpose" of the United Nations for the OAS to impose the quarantine as a defensive measure.

Although the argument just made does not depend on drawing a distinction between "individual" and "collective" self-defense, it must be noted that the precedent created by the quarantine goes no further than multilateral action taken through a regional organization and in accordance with procedures established for that organization. Perhaps the additional safeguards to rash action provided by resort to a regional organization are basic to the case for acting in self-defense without U.N. authorization where there has been no "armed attack." Certainly the OAS finding of a threat to the peace strengthened the United States' case in the Security Council in the sense of helping to establish the facts, and perhaps resort to the OAS underscores an intent on the part of the United States to proceed on a collective basis wherever that may be possible. The U.N. Charter articles on regional arrangements are tied to the "Purposes and Principles of the United Nations"'59 in much the same way as the article 2 (4) prohibition on resort to force, however, and it is doubtful that beyond questioning whether a unilateral determination has the same evidential standing as a regional determination, the quarantine precedent can be limited to collective self-defense. Article 51 of the Charter, which mentions the right of collective self-defense, makes no distinction between that right and the right of individual selfdefense.

In addition to making clear that unilateral action was not contemplated in the quarantine case, the United States by its action also demonstrated to some degree that the Soviet threat should be handled through the United Nations. In his quarantine address, President Kennedy called for a meeting of the Security Council as well as for a meeting of the OAS Organ of Consultation. ${ }^{60}$ The United States

\footnotetext{
50 U.N. CharTER art. 52(1), the basic regional arrangement provision, quoted supra note 38 , concludes with a proviso that "such arrangements or agencies and their activities are consistent with the Purposes and Principles of the United Nations."

${ }^{\circ} 47$ DSB 715, 718.
} 
submitted a draft resolution in the Security Council which would have had the Council note with concern "that nuclear missiles and other offensive weapons have been secretly introduced into Cuba," and take the following two substantive steps:

The Security Council ...

1. Calls as a provisional measure under Article 40 for the immediate dismantling and withdrawal from Cuba of all missiles and other offensive weapons; [and]

2. Authorizes and requests the Acting Secretary-General to dispatch to Cuba a United Nations observer corps to assure and report on complinace with this resolution ....

The draft resolution would also call for the termination of the quarantine "upon United Nations certification" that the "missiles and other offensive weapons" had been dismantled and withdrawn from Cuba. ${ }^{61}$

By taking the question to the United Nations, the United States acknowledged that the United Nations, and specifically the Security Council, has primary responsibility under the Charter for the maintenance of international peace. ${ }^{62}$ The U.S. draft resolution at least implies that the quarantine is subordinate to United Nations collective judgment in that the draft resolution would have established the conditions under which the quarantine must be terminated as no longer warranted. The draft resolution does not, however, call upon the United Nations to replace the OAS quarantine with a United Nations quarantine, or even explicitly to endorse or authorize the continuation of the quarantine as an OAS collective measure. Had the United States affirmatively called for such steps, that move would have aided in establishing the principle that the quarantine was permissible only because time prevented the accomplishment of the same objectives through the United Nations. From this point of view, the U.S. draft resolution ought also to have made specific reference to the speed with which the Soviet Union acted, and to the urgent need for OAS action in order to preserve the possibility of dealing effectively with the Soviet threat through the United Nations.

\footnotetext{
${ }^{61}$ U.N. Doc. No. S/5182 (Oct. 22, 1962), 47 DSB 724. The United States draft resolution was not put to a vote.

B2 U.N. Charter art. 24(1) provides as follows: "In order to ensure prompt and effective action by the United Nations, its Members confer on the Security Council primary responsibility for the maintenance of international peace and security, and agree that in carrying out its duties under this responsibility the Security Council acts on their behalf."
} 
It remains true, however, that the actual act of quarantine was the minimum amount of force necessary to prevent the accomplishment of the Soviet nuclear threat and that the establishment of the quarantine without prior resort to United Nations procedures did not interfere with possible United Nations collective measures. The Security Council or the General Assembly could have condemned the quarantine, as called for by the Soviet Union, ${ }^{63}$ before it could have resulted in any substantial damage either to Cuba or to the Soviet Union. Events in fact demonstrated that despite the existence of the quarantine, the United Nations played a role in securing the removal of the Soviet missiles and strategic bombers which had reached Cuba prior to the imposition of the quarantine. ${ }^{64}$

It has been suggested here that the United Nations may be developed as a forum to which complaints regarding threats of force must be brought before unilateral or regional defensive action may be taken, unless extraordinary circumstances make plain that the available U.N. remedies would not provide effective protection against a grave and immediate danger. It must also be stressed that even when unilateral or regional defensive action is permissible without prior resort to U.N. collective procedures, such action must not supplant U.N. procedures, and that all defensive uses of force, even those responding to armed attack, are subordinate to the Charter in the sense that they are subject to review by the appropriate organ of the United Nations. These procedural devices may provide more workable limits on the defensive use of force than efforts to confine self-defense to "armed attack" or to some other verbal formula developed from general international law.

${ }^{63}$ A Soviet draft resolution introduced in the Security Council, but not voted on, would have recognized "the right of every State to strengthen its defenses," and condemned the quarantine as "aimed at violating the United Nations Charter and at increasing the threat of war." U.N. Doc. No. S/5187 (Oct. 23, 1962).

of On October 24, 1962, Secretary-General U Thant called for suspension of Soviet arms shipments to Cuba, of the construction of "major military facilities and installations in Cuba," and of the quarantine. U.N. Doc. No. S/PV. 1024, at 56-62 (Oct. 24, 1962). Ambassador Stevenson has pointed out that "at a critical moment, when the nuclear powers seemed to be set on a collision course, the Secretary-General's intervention led to the diversion of the Soviet ships headed for Cuba," and that "the United Nations also provided a site where Mr. McCloy and I could meet with Mr. Kuznetsov and the Soviet negotiators for those long weeks to conclude the transaction and bring about the withdrawal of the Soviet bombers." Statement by Adlai E. Stevenson before the Subcommittee on International Organization Affairs of the Senate Committee on Foreign Relations, March 13, 1963, 48 Dep't State Bull. 522, 525-26 (No. 1241, April 8, 1963). See also the joint letter of the U.S. and the U.S.S.R. to the Secretary-General ending the Cuban crisis by withdrawing it from the agenda of the Security Council, U.N. Doc. No. S/5227 (Jan. 7, 1963), 48 Dep't State Bull. 153 (No. 1231, Jan. 28, 1963). 